\title{
Ultra-High-Resolution Monitoring of the Catchment Response to Changing Weather Conditions Using Online Sediment Trapping
}

\author{
Markus Johansson $^{1}\left(\mathbb{D}\right.$, Saija Saarni ${ }^{2}$ (D) and Jouni Sorvari ${ }^{1, *(D)}$ \\ 1 Department of Environmental and Biological Sciences, University of Eastern Finland, P.O. Box 1627, \\ FI-70211 Kuopio, Finland; markus.johansson@uef.fi \\ 2 Department of Geography and Geology, University of Turku, FI-20014 Turku, Finland; saitur@utu.fi \\ * Correspondence: jouni.sorvari@uef.fi; Tel.: +358-40-355-3190
}

Received: 31 March 2019; Accepted: 6 May 2019; Published: 12 May 2019

\begin{abstract}
The purpose of this study was to identify relationships between meteorological and hydrological observations and sediment flux rate changes, in order to better understand catchment dynamics. The meteorological and hydrological observations included local air temperature, wind speed, water temperature, and ice cover, while the sediment flux rate was observed in the lake basin using a modified sediment trap technique. This study demonstrates the advantages of a new online methodology applied in conventional sediment trapping to obtain flux rate information with daily resolution. A prototype of a high-resolution online sediment trap was tested in Savilahti Bay, Lake Kallavesi, eastern Finland, during the period from 22 October 2017 to 6 October 2018. The daily resolutions of meteorological, hydrological, and sediment flux rate data were analyzed using statistical methods. The results indicate relationships between temperature, precipitation, wind speed, and sediment flux rate, but the urban site also showed erosional changes due to anthropogenic land use. Sediment flux ceased during winter season and spring floods were recorded as pronounced peaks in sediment flux, while the growing season showed generally higher sediment accumulation rates. This research also provides valuable information on the catchment response to short-term weather events. The influence of a storm led to larger sediment flux for several days. The importance of wind speed and frost formation on sedimentation, which has been difficult to address due to trap deployment times of typically several months, is now supported. Used together with varved sediment archives, online sediment trapping will facilitate the interpretation of paleoclimatic proxy records and modeling of detailed weather and erosion conditions that are related to climate change.
\end{abstract}

Keywords: sedimentation; flux rate; catchment dynamics; ultra-high resolution; environmental monitoring; novel technology methodology

\section{Introduction}

Annually laminated (varved) sediments have shown their importance in paleoclimatological and environmental studies [1-3]. A high temporal resolution up to subannual scale allows robust dating [1] as well as investigation of past hydroclimatic and temperature variability, even in a season-specific manner [4-7]. Varves, formed as a consequence of seasonal cycles in sediment availability and production [2], are highly dependent on catchment characteristics and environmental conditions [2,8]. This leads to their sensitivity in reflecting changes in climatic conditions over time in different climatic zones [9-13] and underlines the need to understand each varve record with respect to their individual catchment and climate characteristics [2,4]. Understanding the detailed mechanisms that mediate hydroclimatic changes in sedimentary records is critical for paleoclimatic and environmental 
interpretations $[2,4,14,15]$. Understanding of the process is further gained by using sediment trap monitoring, which reveals seasonal changes in sedimentary material in detail [14-18].

Sediment trapping is a classical technique used to acquire time series of sediment flux rates and variations in sedimentary composition in aquatic environments [14,15]. In order to investigate the sediment flux rate with respect to meteorological and hydrological effects, high-resolution observations from the study site are required. Using sequential sediment trap monitoring with seasonal deployment intervals, it has been possible to gain a detailed understanding of the seasonal controls on catchment processes, erosion, production, and sediment deposition [14-18]. However, investigating the importance of a single short-term meteorological event in sediment deposition using the sediment trap technique is difficult. Traditionally, sediment trap time series are collected with a resolution of a few months. Nowadays, higher-resolution trap monitoring is desired and datasets of monthly and biweekly resolution are typical $[14,19,20]$. Thus, the influences of short-term meteorological and hydrological events on flux rate changes are not recorded, but are addressed on the scale of weeks. Furthermore, wind and frost formation, which are obscured by the more dominant forcing factors, have been suggested to influence sediment accumulation [4,21-23], but so far have been addressed using indirect evidence and statistical approaches. Using seasonal trap monitoring, these questions are difficult to answer, because other erosional events, such as spring floods or numerous rainy days, have dominated the sedimentation. So far, according to our knowledge, no systematic attempts have been carried out to measure the changes in sediment accumulation during, for example, a single storm event. Therefore, a monitoring technique that can obtain ultra-high-resolution time series from flux rates in aquatic sites is desired.

Trapping methods can be divided into two categories: passive sampling traps and traps with sample bottles attached in an automatic revolving wheel. Passive trapping is a commonly used method in lake studies, with deployment intervals varying from a few weeks to several months. A revolving wheel can be used to sample with higher temporal resolution. However, due to the restricted number of collector tubes in a revolver, sampling longer time series with daily resolution is rare due to increased operating costs and effort required. The modern online technology applied to sediment trap monitoring would enable longer and higher-resolution time series of flux rate variability and therefore a more detailed understanding of the processes related to sediment accumulation with respect to anthropogenic land use or single meteorological events.

Computer tomography methods are noninvasive and nonintrusive ways to measure and image the interiors of objects. Typically, tomographic imaging applications are utilized in medical and industrial fields but can be applied in other fields where there is a need to obtain images inside objects. Computer tomographic imaging combines multiple projections of an object into a cross-sectional image. Projections are measured by scanning the object from different angles. Tomographic results are in two or three dimensions, depending on the measurement setup. Three-dimensional images describe the height, length, and volume of the object.

We applied tomographic imaging to sediment traps in order to measure volume changes inside the sediment trap collector tube and determine flux rate variations semicontinuously with daily time resolution. This paper presents a methodology for ultra-high-resolution online sediment trapping to investigate daily changes in sediment flux rate with respect to meteorological and hydrological observations. This technique can be applied to understand the importance of different meteorological and hydrological events in catchment erosion and sedimentation in detail.

\section{Materials and Methods}

\subsection{Site Description}

Lake Kallavesi is a large water body located in eastern Finland surrounding the city of Kuopio. It is located in the boreal vegetation zone, with annual mean temperature of $+3{ }^{\circ} \mathrm{C}$, and mean temperature of the coldest and warmest months is $-10^{\circ} \mathrm{C}$ (January) and $+17^{\circ} \mathrm{C}$ (July), respectively [24]. Annual 
precipitation is about $644 \mathrm{~mm} /$ year, of which approximately half is in the form of snow. The lake is covered by ice for about 6 months, typically from November to April [25].

The complex Lake Kallavesi basin was formed after the Weichselian ice sheet retreated more than 9500 years ago [26,27]. It includes several semiclosed basins detached from the main water body by glacial deposits such as eskers, but also by bedrock shear zones and Precambrian domes. One semiclosed basin, Savilahti Bay, was selected as the study site because it has several advantages. With the University of Eastern Finland campus located on its shore, Savilahti Bay was an ideal place to test the prototype of the sediment trap system because of the ease of access to the trap location in case the online data showed interruption, disconnection, or other problems. In addition to the ease of trap maintenance, the advantages are undisturbed sedimentation in the deepest part of the basin and, first and foremost, the meteorological station located on the shore to enable the evaluation of the importance of weather events in sediment accumulation. The surface area of the Savilahti Basin is $0.345 \mathrm{~km}^{2}$ and the maximum water depth is $7 \mathrm{~m}$ (Figure 1). Savilahti Bay is detached from the main water body of Lake Kallavesi by two sills, reducing the water depth to $1 \mathrm{~m}$ in eastern and northern parts of the basin. Thus, the sedimentation of Savilahti Bay can be considered to mostly represent its catchment instead of the entirety of Lake Kallavesi. There are two narrow streams discharging to Savilahti Bay from the northeastern island and southwestern coast. The bay catchment is composed of coarse-grained material including quaternary sand deposits and sand moraines, former lacustrine fine-grained sediments, and bedrock outcrops. Savilahti Bay is located at $81 \mathrm{~m}$ a.s.l. and the northeastern side of the bay is sheltered by a high hill slope ( $140 \mathrm{~m}$ a.s.l.). At present there are human residences, road systems, and other infrastructure on the catchment in addition to boreal pine forests.

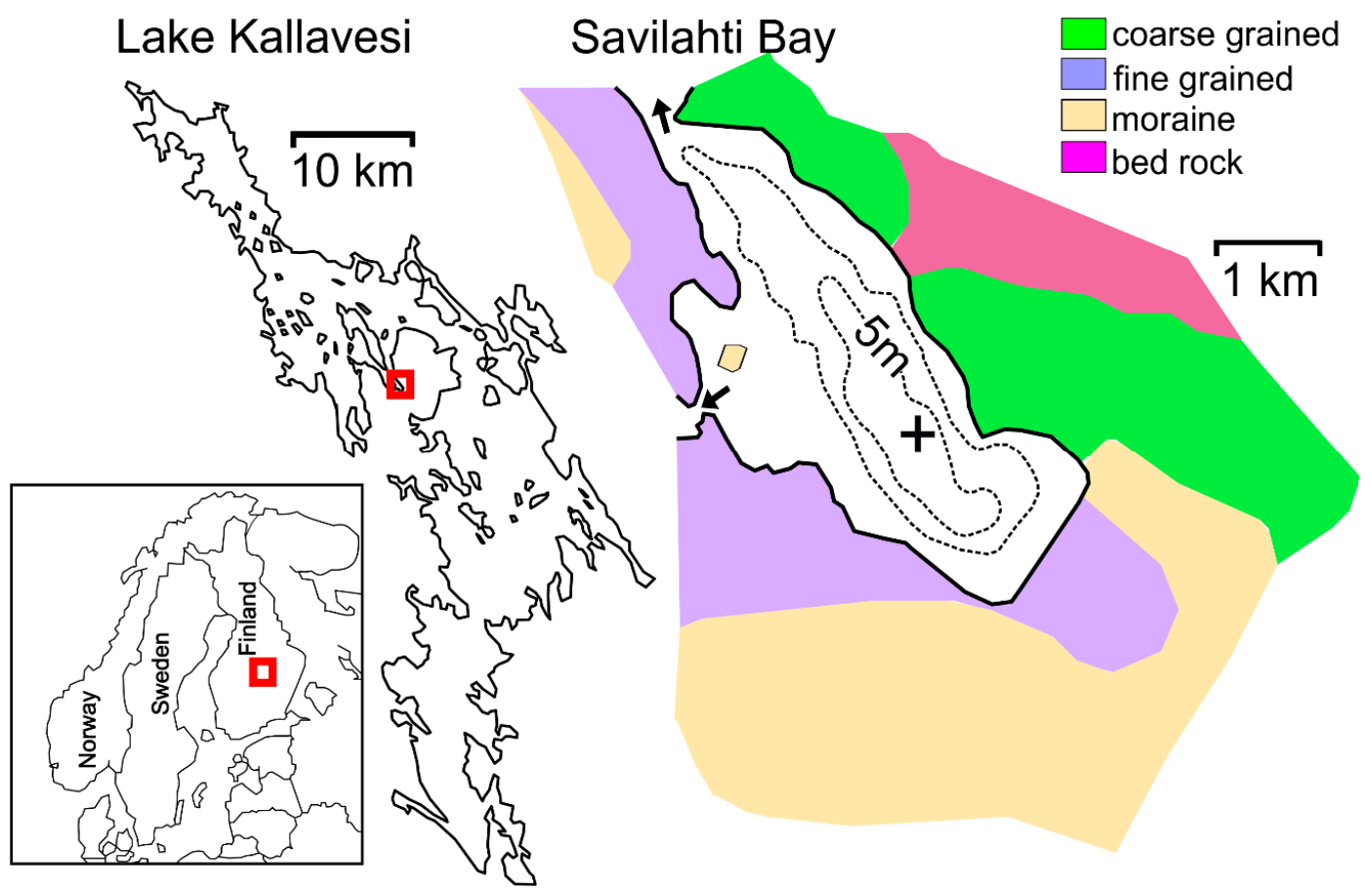

Figure 1. Location of Savilahti Bay and the online sediment trap site in the deepest part of the basin (marked with + ).

Lake Kallavesi is a dimictic brown-water lake, which is a very typical lake type in Finland. Savilahti Bay suffers hypoxic conditions during the winter stratification. According to the measurements at the study site in February of 2016-2018, the oxygen concentration in bottom waters was 8.1, 4.2, and $4.4 \mathrm{mg} / \mathrm{L}$, respectively. Thus, with its size, catchment, and water characteristics, Savilahti Bay resembles the previously reported Finnish lakes with annually laminated sediments $[4,9,15,21,23]$. 


\subsection{Field Work}

A prototype of a high-resolution online trap (Figures 2 and 3) was installed at the deepest point of the basin $1 \mathrm{~m}$ above the sediment surface, i.e., to a depth of $6 \mathrm{~m}$. During the study, the sediment accumulation and the state of the equipment were inspected on daily basis. An anchored buoy that sends measurements over a mobile network was installed near the online trap (Figure 2a) and left in place for the duration of the study, including the period of ice cover. The daily resolution of meteorological and hydrological data was obtained using open data from the Finnish Meteorological Institute [24] and Finland's environmental administration [25]. Ice-cover information was based on visual observation. Sediment flux rate and meteorological and hydrological observations were collected during the period from 22 October 2017 to 6 October 2018 in Savilahti Bay of Lake Kallavesi, Kuopio, Finland. The sediment trap was collected on 11 November 2017, 10 May 2018, 28 July 2018, and 6 October 2018.

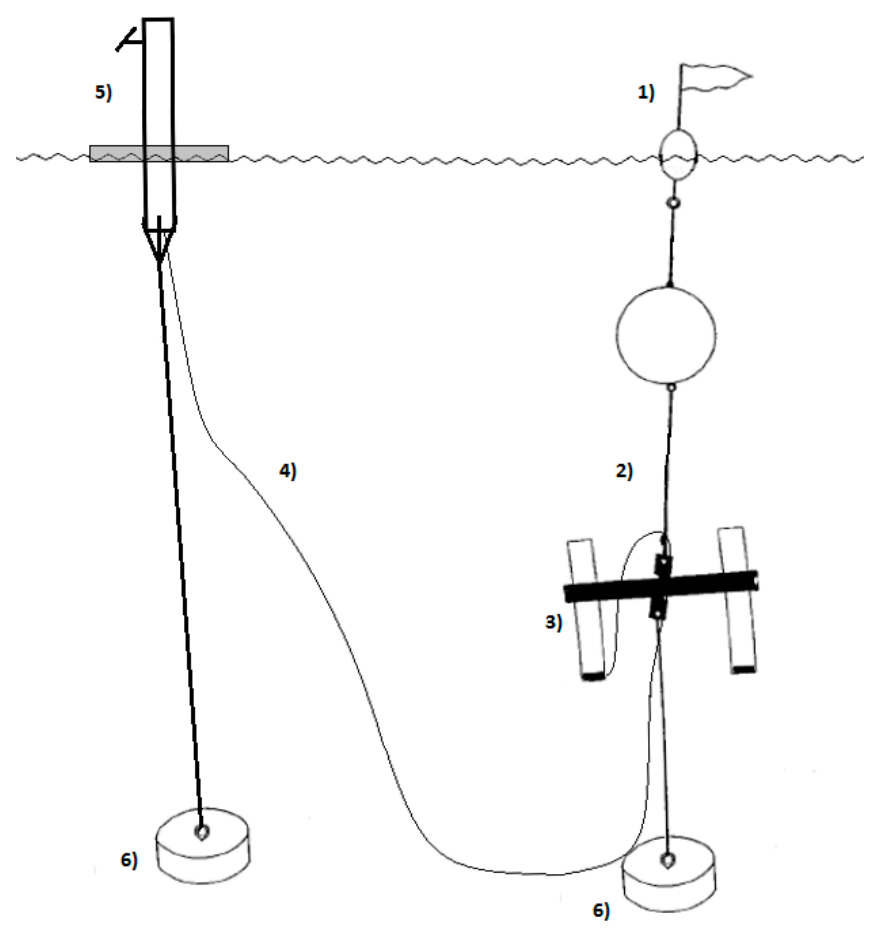

(a)

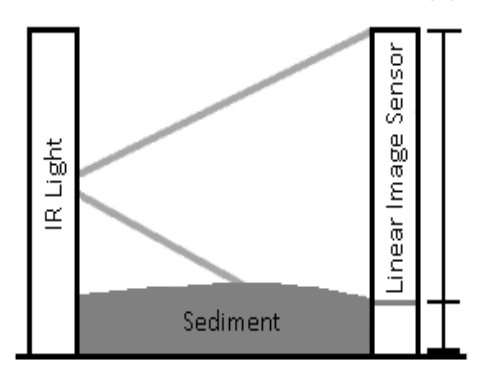

(b)

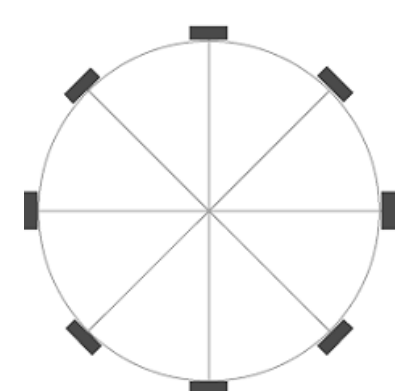

(c)

Figure 2. (a) Schematic illustration showing the online trap configuration: (1) signal buoy, (2) sediment trap, (3) trap collector tube with tomography device, (4) cable connecting tomography device with solar panel energy supply and Internet network, (5) float providing Internet connection and energy supply, and (6) anchors. (b) Cross-section illustration of tomographic scanning at the lower part of the modified trap collector tube, and (c) location of optical transmitters and receiver pairs at the bottom of the modified trap tube. 


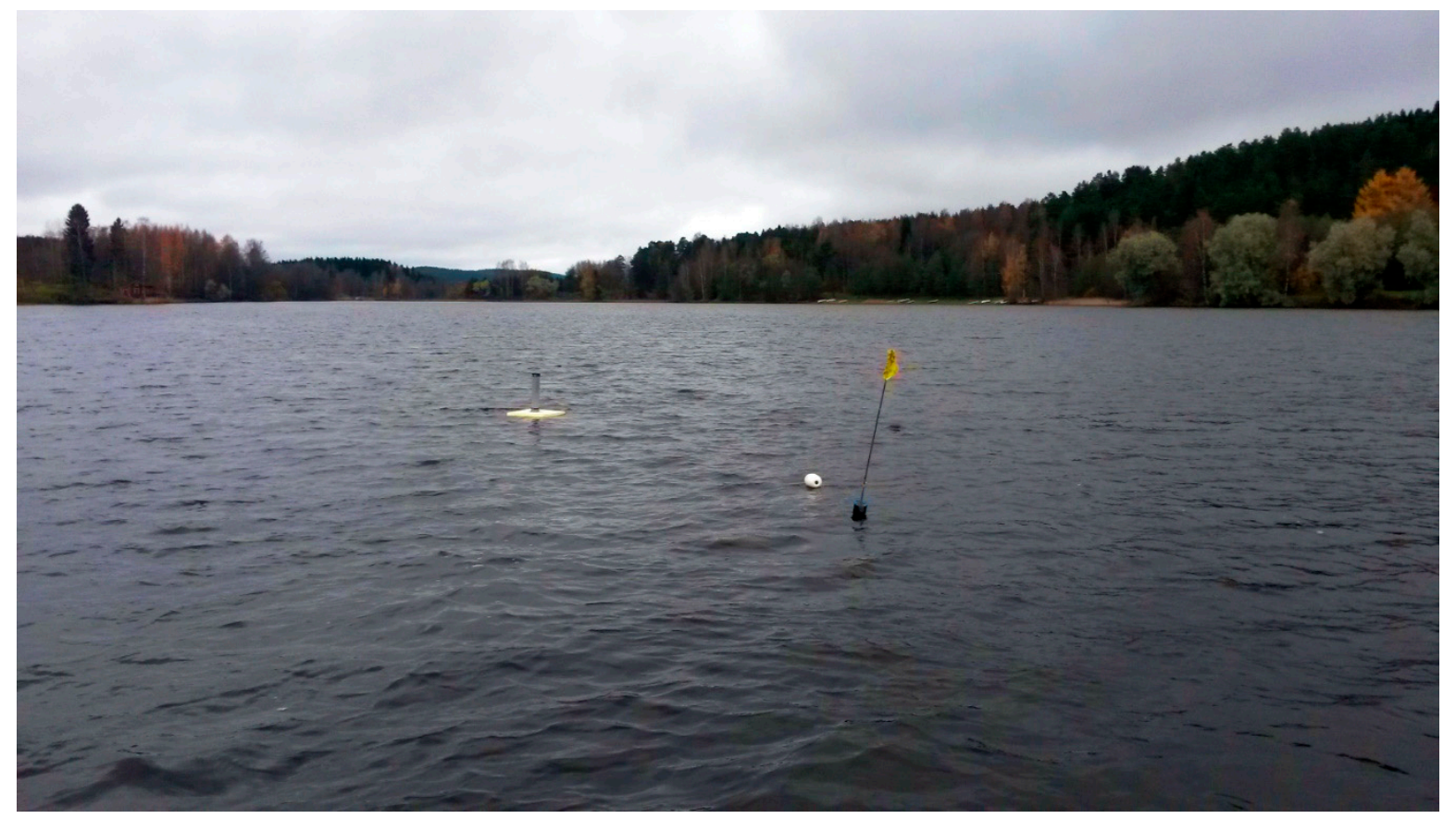

Figure 3. Online trap in Savilahti Bay basin at a depth of $6 \mathrm{~m}$ under the flag sign. Anchored float behind flag sign is the base station for the online trap, which sends measurements to the Internet over a mobile network.

\subsection{Daily Measurement of Sediment Flux}

Online trapping was used to investigate daily changes of sedimentation flux rate. A conventional sediment trap with 2 collector tubes was modified for this purpose. Computed tomography scanning equipment was adjusted in collector tube 1, while collector tube 2 was left as a reference tube (Figure 2a). Computed tomography, where the resulting image is a volumetric representation of structures in the trap tube, was applied to measure the daily change in sediment volume (Figure 2b). The trap tube was surrounded by 8 optical transmitter (infrared light) and receiver (linear camera) pairs in the inner surface at the lower part of the tube (Figure 2c). Optical transmitters and receivers performed tomographic scans of the trap tube interior. Computer tomography scans are based on optical measurements, which measure light attenuation from different angles. Accumulated sediment causes light attenuation by absorbing light energy. Water affects light transfer, but significantly less than accumulated sediment. This attenuation is captured by imaging sensors from opposite sides as light sources. Imaging sensors are positioned vertically to capture changes in height. Scanning was performed by turning light sources on and off sequentially and capturing light attenuation by imaging sensors simultaneously from the opposite side in a similar sequence. Captured light attenuation represents the light absorption profile of accumulated sediment from the height direction, i.e., projection of accumulated sediment. Profiles captured from 8 different angles were processed by a filtered back projection algorithm to a volumetric image. The measurement interval was $1 \mathrm{~h}$, and data were transferred as an email attachment once a day. The operating principle and a detailed technical description of the online sediment trap methodology are provided in [28]. The measurement range in the height direction was 0 to $8.125 \mathrm{~mm}$, and with a trap diameter of $56.5 \mathrm{~mm}$, the maximum volume was about $19.9 \mathrm{~mL}$. Accumulation was followed online so that the maximum volume would not be exceeded.

The sediment trap was collected 4 times during the year in order to verify the volume of accumulated sediment and empty the trap tube to ensure that the maximum technical volume was not exceeded. Accumulated sediment volume was measured manually from the trap tube in a measuring cylinder, in order to compare tomography scan volume to actual sediment volume in the tube. Sediment collection was performed by taking the whole contents of the trap, sediment and water, to a $5 \mathrm{~L}$ sample 
vessel. Collected sediment and water were stored in the sample vessel for further processing. To determine sediment volume, first the amount of water was reduced from the sample vessel to about $80 \mathrm{~mL}$. Then, the sediment and remaining water were poured into a $100 \mathrm{~mL}$ measuring cylinder and left to settle for about 1 day. After settling, sediment volume was determined manually.

\subsection{Meteorological and Hydrological Observations}

Meteorological observations of open data from the Finnish Meteorological Institute were utilized [24]. The meteorological station is located only $200 \mathrm{~m}$ from the sediment trap. Meteorological data include air temperature $\left({ }^{\circ} \mathrm{C}\right)$, air humidity $(\% \mathrm{RH})$, dew point $\left({ }^{\circ} \mathrm{C}\right)$, precipitation $(\mathrm{mm})$, pressure $(\mathrm{hPa})$, wind speed $(\mathrm{m} / \mathrm{s})$, wind direction $\left(^{\circ}\right)$, snow depth $(\mathrm{cm})$, visibility $(\mathrm{m})$, water precipitation $(\mathrm{mm})$, and snow precipitation $(\mathrm{mm})$. The hydrological observations were from local measurements from the study site and an open data service provided by Finland's environmental administration. Local hydrological measurements included water temperature from 1-6 $\mathrm{m}$ depth within $1 \mathrm{~m}$ intervals. Depth is marked in meters in the results as $1-6$, where 1 is near the water surface and 6 is near the lake bottom.

Hydrological data from Finland's environmental administration consisted of the following parameters: water surface temperature $\left({ }^{\circ} \mathrm{C}\right)$ from a depth of $1 \mathrm{~m}$, water level $(\mathrm{cm})$, water flow $\left(\mathrm{m}^{3} / \mathrm{s}\right)$, and depth of ground frost $(\mathrm{cm})$. Ice cover information is based on visual observations of Savilahti Bay, recorded in the diary according to the situation in the bay. The ice cover data are interpreted as 0 for liquid water and 1 for ice cover. Ground frost data accuracy is about $1-2 \mathrm{~cm}$; this specified accuracy is used to discriminate the ground frost variable to define 2 different situations. The ground frost variable is used as a grouping variable: 1 if the frost is more than $1 \mathrm{~cm}$ in depth and 0 if less than $1 \mathrm{~cm}$. Ground frost group data are interpreted as unfrozen soil (0) and frost at least $1 \mathrm{~cm}$ deep (1).

Wind direction is a cyclic variable, which is transformed to vector values by Equations (1) and (2). Equation (1) is used to transform the wind direction to the north-south vector, and Equation (2) is used to transform the wind direction to the west-east vector:

$$
\begin{aligned}
& \text { Wind direction (north-south) }=\text { wind speed } \mathrm{m} / \mathrm{s} \times \sin (\text { wind direction degrees) } \\
& \text { Wind direction (west-east) }=\text { wind speed } \mathrm{m} / \mathrm{s} \times \cos \text { (wind direction degrees) }
\end{aligned}
$$

\subsection{Statistical Analysis}

All data, sediment accumulation, and meteorological and hydrological observations were combined into one dataset for statistical analysis. Statistical analysis was processed with SPSS software version 25.0 [29]. First, data were preprocessed by setting outlier values to variables and then calculating daily averages for continuous variables from one-hour resolution data. Discrete variables of water and snow precipitation were also preprocessed by setting outlier values to variables but calculating the daily sum instead of averaging. Pearson's correlation coefficient and scatter plots were used to measure linear dependencies of variables. The combined daily resolution dataset row count was 350. The outlier values were set for sedimentation flux rate to values outside of 0.01 to $1.00 \mathrm{~mL} /$ day. The meteorological and hydrological measurements were normally distributed, therefore no outliers were excluded. The local water temperature dataset row count was 278 for depths of 1 to $6 \mathrm{~m}$. Local water temperature data failed to record temperatures from 27 July 2018 due hardware failure. The rest of the rows (279 to 350 ) of water temperature to one-meter depth were replaced by water surface temperature data from Finland's environmental administration. The statistical analysis was performed using grouping information to separate the effect of ice cover for cases where meteorological events may affect sedimentation flux rate. As another way to study the influence of weather conditions on sedimentation, ice cover observations were used to separate the dataset for 2 different cases. Air temperature, snow depth, and all hydrological observations were examined for the whole dataset. 


\section{Results}

The monitored sediment flux rate showed great daily variation. The measured sediment accumulation varied from 0 to $1.73 \mathrm{~mL} /$ day, the mean accumulation was $0.11 \mathrm{~mL} /$ day, and the median was $0.10 \mathrm{~mL} /$ day during the one-year test period. The total accumulation for the year was $39 \mathrm{~mL}$, of which $3.65 \mathrm{~mL}$ accumulated during winter (November-March), $8.07 \mathrm{~mL}$ during spring (April-May), $18.38 \mathrm{~mL}$ during summer (June-August), and $8.89 \mathrm{~mL}$ during autumn (September-October; note that autumn accumulation is the combined sum from 22-31 October 2017 and 1 September to 6 October 2018).

The sediment volume was measured manually in order to verify the tomographic scan volume measurements. Sediment collection dates and sediment volumes (in $\mathrm{mL}$ ) are shown in Table 1. The table shows sediment volume measured by the online trap and manually; the last column of the table shows differences between online and manually measured volume. Total accumulated sediment was $39 \mathrm{~mL}$ as measured by the online device and $40.8 \mathrm{~mL}$ by manual measurement.

Table 1. Sediment collection dates and volumes.

\begin{tabular}{cccc}
\hline Sediment Collection Date & Online Measurement $(\mathbf{m L})$ & Manual Measurement $(\mathbf{m L})$ & Difference $(\mathbf{m L})$ \\
\hline 11.11 .2017 & 3.0 & 2.5 & 0.5 \\
10.5 .2018 & 6.9 & 6.5 & 0.4 \\
28.7 .2018 & 14.7 & 14.0 & 0.7 \\
6.10 .2018 & 14.4 & 17.8 & -3.4 \\
\hline
\end{tabular}

\subsection{Ultra-High-Resolution Sediment Flux Rate with Meteorological and Hydrological Observations}

The sedimentation flux rate and meteorological and hydrological observations represent seasonal variations over the investigated time period of one year. Measured variables, units, and descriptive statistics are shown in Table 2. Time series figures represent variations and relationships between variables: sedimentation flux rate with meteorological and hydrological observations (Figures 4-6). Time series figures were interpreted as different seasonal situations.

Table 2. Descriptive statistics of variables used in study.

\begin{tabular}{|c|c|c|c|c|c|c|c|}
\hline Variable & Unit & $\mathbf{N}$ & Minimum & Maximum & Mean & Median & $\begin{array}{c}\text { Std. } \\
\text { Deviation }\end{array}$ \\
\hline Sedimentation Flux rate & $\mathrm{mL} /$ day & 350 & 0.00 & 1.73 & 0.11 & 0.10 & 0.23 \\
\hline Air temperature & ${ }^{\circ} \mathrm{C}$ & 350 & -21.10 & 25.37 & 5.02 & 13.27 & 10.87 \\
\hline Wind speed & $\mathrm{m} / \mathrm{s}$ & 350 & 0.88 & 5.83 & 2.49 & 2.40 & 0.90 \\
\hline Wind gust & $\mathrm{m} / \mathrm{s}$ & 350 & 1.56 & 11.18 & 4.70 & 4.45 & 1.77 \\
\hline Wind direction & $\circ$ & 350 & 58.83 & 350.92 & 199.33 & 191.52 & 70.73 \\
\hline Snow depth & $\mathrm{Cm}$ & 350 & 0.00 & 93.88 & 22.41 & 50.93 & 29.75 \\
\hline Water precipitation & $\mathrm{mm}$ & 350 & 0.00 & 37.00 & 1.11 & 2.10 & 3.58 \\
\hline Snow precipitation & $\mathrm{mm}$ & 350 & 0.00 & 18.50 & 0.62 & 2.00 & 1.99 \\
\hline Water temperature at depth of: & ${ }^{\circ} \mathrm{C}$ & & & & & & \\
\hline $1 \mathrm{~m}$ & & 350 & 0.06 & 24.70 & 7.47 & 14.40 & 8.54 \\
\hline $2 \mathrm{~m}$ & & 278 & 0.07 & 18.81 & 4.97 & 1.32 & 6.44 \\
\hline $3 \mathrm{~m}$ & & 278 & 0.06 & 16.58 & 4.36 & 1.56 & 5.24 \\
\hline $4 \mathrm{~m}$ & & 278 & 0.06 & 13.70 & 3.89 & 1.73 & 4.19 \\
\hline $5 \mathrm{~m}$ & & 278 & 0.13 & 12.41 & 3.63 & 2.07 & 3.38 \\
\hline $6 \mathrm{~m}$ & & 278 & 0.12 & 10.27 & 3.37 & 2.56 & 2.67 \\
\hline Ground frost & $\mathrm{Cm}$ & 183 & 0.00 & 5.00 & 1.00 & 1.40 & 1.43 \\
\hline Ice cover & $\begin{array}{l}0 \text { (no), } \\
1 \text { (yes) }\end{array}$ & 350 & 0 & 1 & - & - & - \\
\hline Construction & $\begin{array}{l}0 \text { (no), } \\
1 \text { (yes) }\end{array}$ & 350 & 0 & 1 & - & - & - \\
\hline Ground frost (group variable) & $\begin{array}{l}0 \text { (no), } \\
1 \text { (yes) }\end{array}$ & 350 & 0 & 1 & - & - & - \\
\hline
\end{tabular}




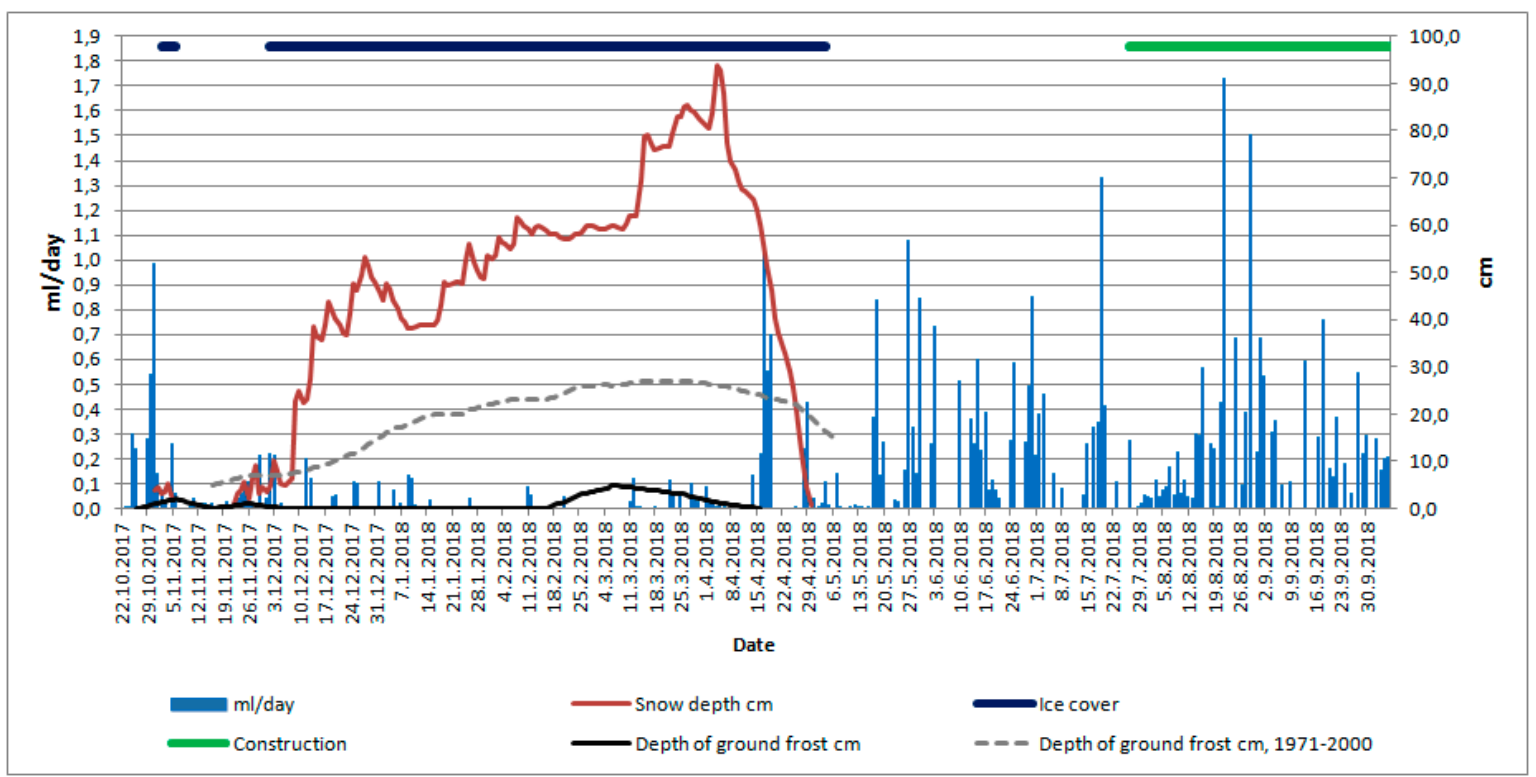

Figure 4. Daily sedimentation flux rate of Savilahti Bay from 22 October 2017 to 6 October 2018. Bar diagram shows sediment flux rate in $\mathrm{mL} /$ day, line diagram shows snow depth in $\mathrm{cm}$ (red line), ground frost depth in cm (black line), and monthly averaged ground frost depth from 1971 to 2000 in cm (dotted gray line). Note that ground frost in $\mathrm{cm}$ means depth below the ground surface. Bold lines on top of diagrams show ice cover (dark blue) and construction (green) events during the investigation period.

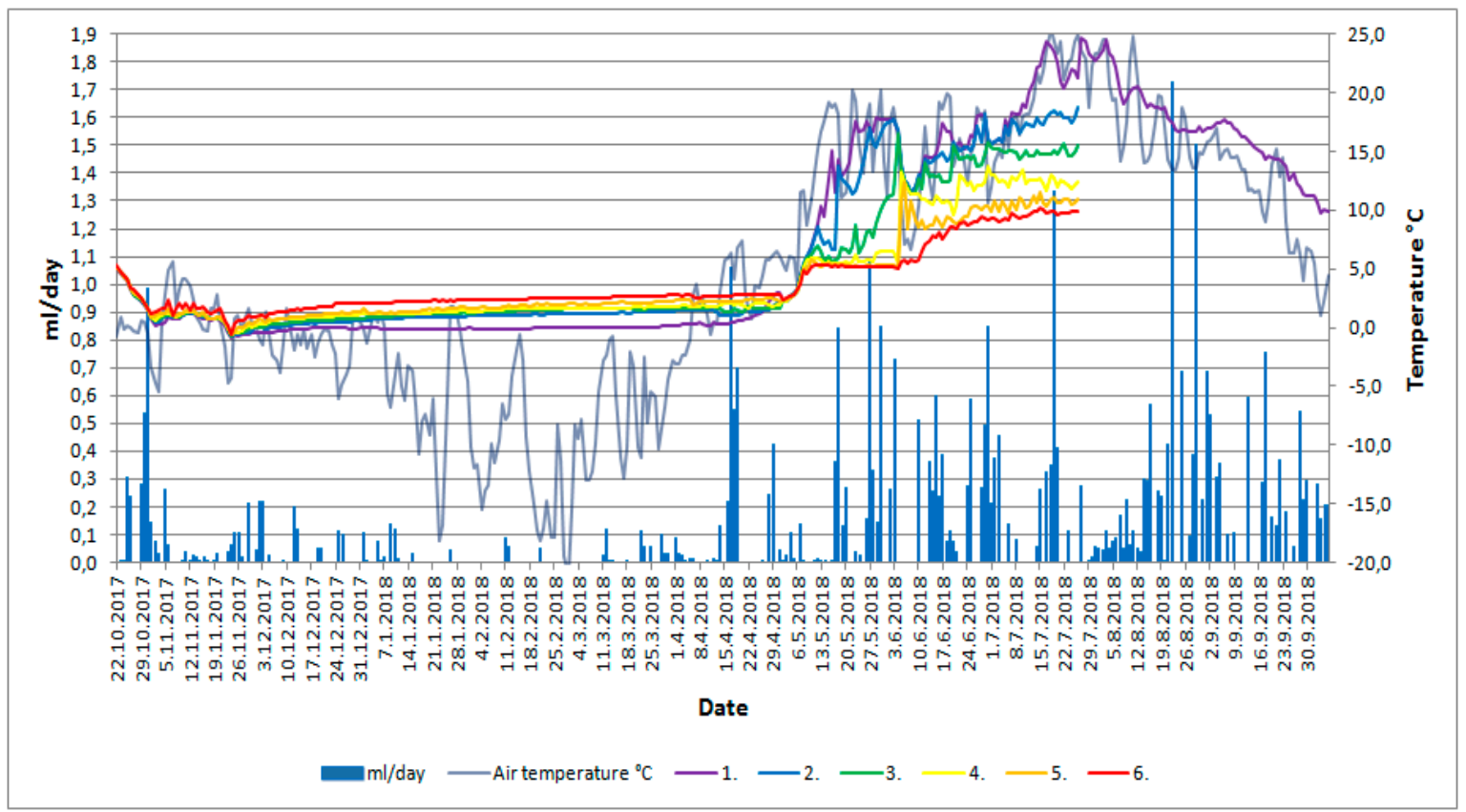

Figure 5. Daily sedimentation flux rate with respect to air temperature and basin water temperature at depths of 1 to $6 \mathrm{~m}$, with one-meter interval, in Savilahti Bay from 22 October 2017 to 6 October 2018. Bar diagram shows sedimentation flux rate in $\mathrm{mL}$ /day and line diagram shows temperatures during investigation period: air (blue transparent line), water from $1 \mathrm{~m}$ depth (violet line), $2 \mathrm{~m}$ depth (blue line), $3 \mathrm{~m}$ depth (green line), $4 \mathrm{~m}$ depth (yellow line), $5 \mathrm{~m}$ depth (orange line), and $6 \mathrm{~m}$ depth (red line). Sedimentation flux rate increased when air temperature was above $0{ }^{\circ} \mathrm{C}$ and decreased when air temperature was below $0{ }^{\circ} \mathrm{C}$. Note that water temperature from depths of 2 to $6 \mathrm{~m}$ are missing due hardware failure starting on 27 July 2018. 


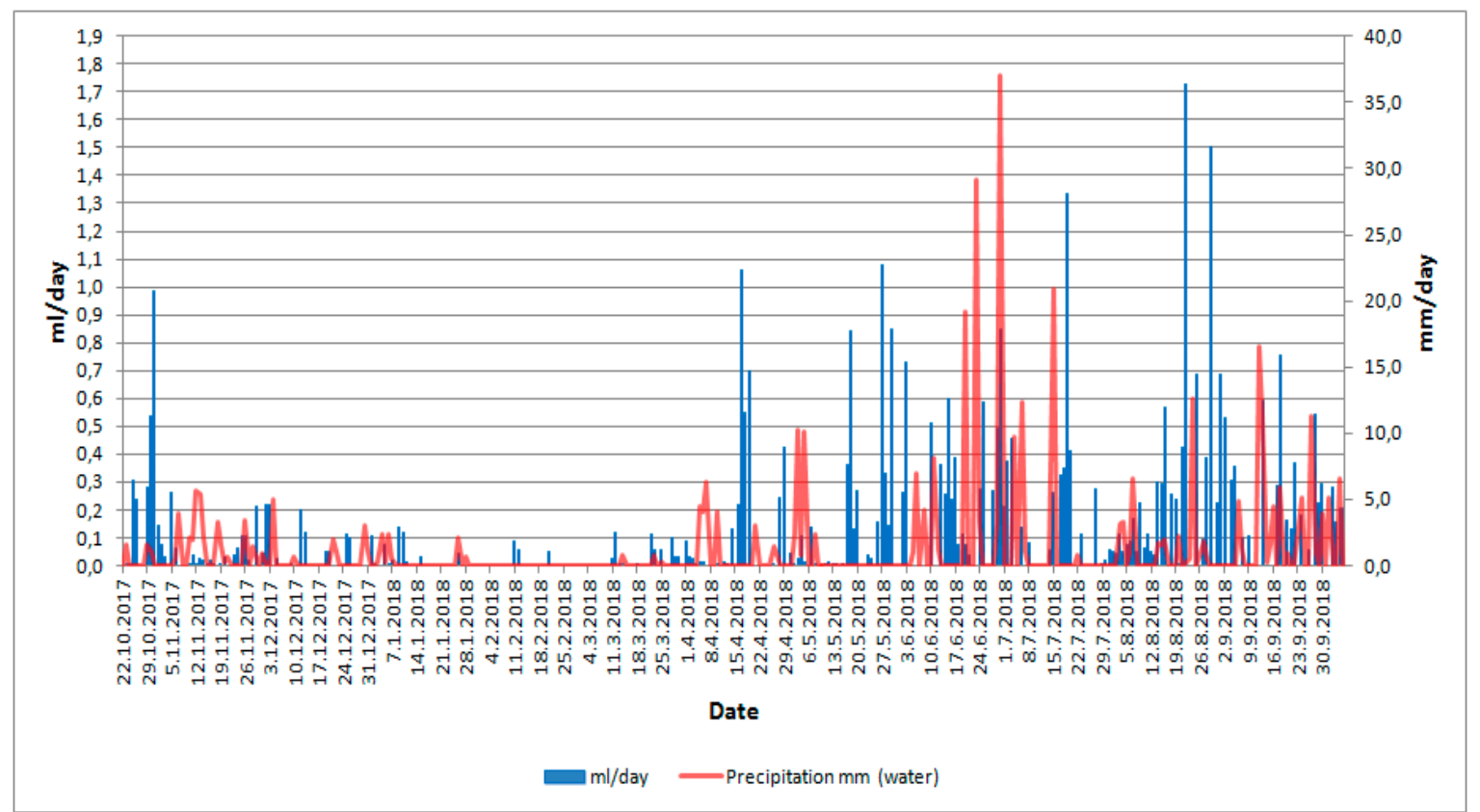

Figure 6. Daily sedimentation flux rate from Savilahti from 22 October 2017 to 6 October 2018. Bar diagram shows sedimentation flux rate in $\mathrm{mL} /$ day and line diagram shows water precipitation in $\mathrm{mm} /$ day (red line) during the investigation period.

\subsection{Statistical Analysis Results}

Pearson correlation coefficient was computed to assess the relationship between the sedimentation flux rate and meteorological and hydrological observations. Statistical correlations were calculated between every variable of the dataset, and statistically significant results where correlation coefficient $p$-value was $<0.05$ are shown in Tables 3 and 4 .

Table 3. Pearson correlation between sediment flux rate and meteorological observations.

\begin{tabular}{ccccc}
\hline $\begin{array}{c}\text { Flux Rate } \\
(\mathbf{m L} / \text { day })\end{array}$ & $\begin{array}{c}\text { Air Temperature } \\
\left({ }^{\circ} \mathbf{C}\right)\end{array}$ & $\begin{array}{c}\text { Wind Speed } \\
(\mathbf{m} / \mathbf{s})\end{array}$ & $\begin{array}{c}\text { Wind Direction } \\
\text { (West-East) }\end{array}$ & $\begin{array}{c}\text { Precipitation } \\
(\mathbf{m m} \text { Water) }\end{array}$ \\
\hline$r$ & $0.31^{1}$ & $0.31^{2}$ & $0.20^{2}$ & $0.35^{1}$ \\
$p$ & $<0.001$ & 0.02 & 0.045 & 0.01 \\
$\mathrm{~N}$ & 350 & 54 & 106 & 54 \\
\hline
\end{tabular}

${ }^{1}$ Correlation is significant at the 0.01 level (2-tailed). ${ }^{2}$ Correlation is significant at the 0.05 level (2-tailed).

Table 4. Pearson correlation between sediment flux rate and hydrological observations.

\begin{tabular}{ccccc}
\hline $\begin{array}{c}\text { Flux Rate } \\
\text { (mL/day) }\end{array}$ & $\mathbf{1}$ & $\mathbf{2}$ & $\mathbf{3}$ & $\mathbf{4}$ \\
\hline$R$ & $0.31^{1}$ & $0.34^{1}$ & $0.30^{1}$ & $0.28^{1}$ \\
$P$ & $<0.001$ & 0.02 & 0.01 & $<0.001$ \\
$\mathrm{~N}$ & 350 & 278 & 278 & 278 \\
\hline Flux Rate & $\mathbf{5}$ & $\mathbf{6}$ & Ice Cover & Snow Depth (cm) \\
(mL/day) & & & $-0.28^{1}$ & $-0.26^{1}$ \\
$R$ & $0.28^{1}$ & $0.28^{1}$ & $<0.001$ & $<0.001$ \\
$P$ & 0.01 & $<0.001$ & 350 & 350 \\
\hline $\mathrm{N}$ & 278 & 278 &
\end{tabular}

\footnotetext{
${ }^{1}$ Correlation is significant at the 0.01 level (2-tailed).
} 
Comparing the Pearson correlation coefficient between sedimentation flux rate and meteorological observations (Table 3) shows a positive correlation between temperature, wind speed, wind direction, and water precipitation. The positive correlation between sediment flux rate and air temperature $(r=0.31, \mathrm{~N}=350, p<0.001)$ is summarized in a scatter plot (Figure 7a). Increases in sedimentation flux rate were correlated with increases in air temperature.

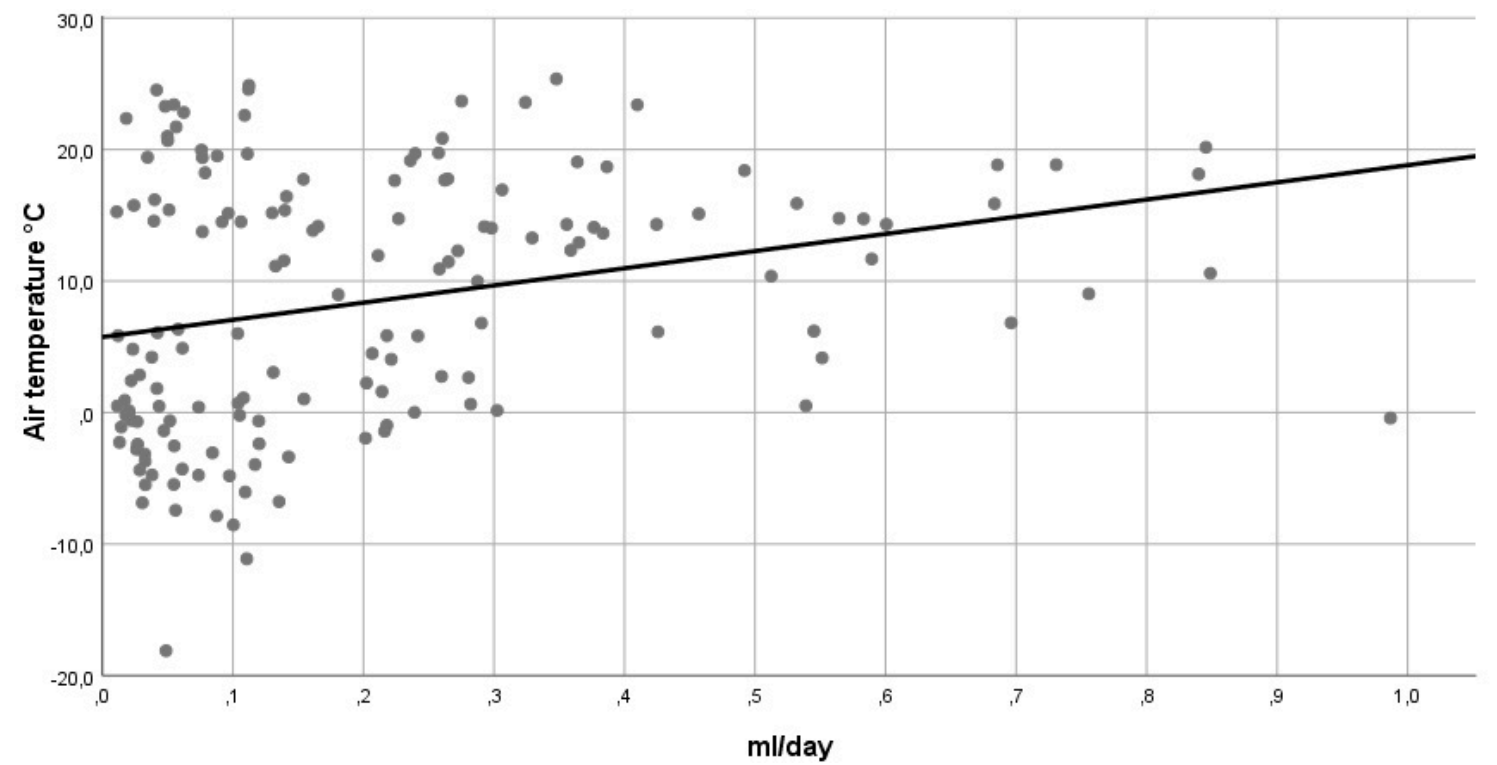

(a)

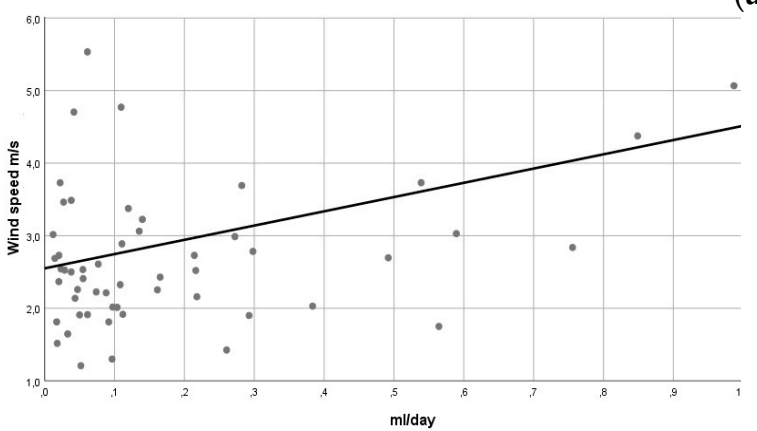

(b)

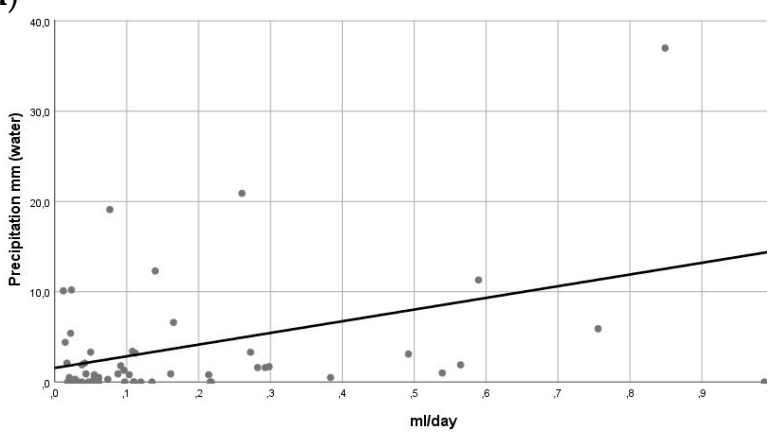

(c)

Figure 7. Linear relationship between (a) air temperature, (b) wind speed, and (c) water precipitation and daily sedimentation flux rate.

Overall, there was a medium positive correlation between sedimentation flux rate and wind speed $(r=0.31, \mathrm{~N}=54, p=0.02$; Table 3, Figure 7b). Increased sediment flux was correlated with enhanced wind speed. A weak positive correlation between flux rate and wind direction was also found $(r=0.20$, $\mathrm{N}=106, p=0.045)$, suggesting increased sedimentation during windy periods. Finally, there was a medium positive correlation between water precipitation and flux rate $(r=0.35, \mathrm{~N}=54, p=0.01)$. Increased sedimentation flux rate was correlated with increased water precipitation (Table 3, Figure 7c).

Positive and negative correlation coefficients between sedimentation flux rate and hydrological observations were found (Table 4). A medium negative correlation was observed between sediment flux rate and snow depth $(r=-0.26, \mathrm{~N}=350, p<0.001)$. Increased sediment flux rate was correlated with decreased snow depth. Flux rate and water temperature at depths of 1-6 m showed a positive correlation (Table 4), while a medium negative correlation was found between sediment accumulation and occurrence of ice cover $(r=-0.28, \mathrm{~N}=350, p<0.001)$. Sediment flux rate was decreased during periods of ice cover. 
The 3-day precipitation event during 10-12 June with daily precipitation of $4.1 \mathrm{~mm}, 8.1 \mathrm{~mm}$, and $1.2 \mathrm{~mm}$, respectively, was followed by a significant increase in daily sediment accumulation on 13 June, which lasted up to 5 days. Single one-day storm events on 23 June, 30 June, and 15 July (see Figure 6) caused water precipitation of 29.2, 37.0, and $20.9 \mathrm{~mm}$, respectively, followed by increased sediment accumulation on 24 June, 1 July, and 17 July with durations of 2, 4, and 4 days. It is noteworthy that in between precipitation events, the sediment flux rate decreased to a much lower level, even under the detection limit. The 6-day precipitation event during 10-15 November, with daily precipitation of $2.1 \mathrm{~mm}, 1.9 \mathrm{~mm}, 5.7 \mathrm{~mm}, 5.4 \mathrm{~mm}, 2.1 \mathrm{~mm}$, and $0.3 \mathrm{~mm}$, respectively, was followed by a minor increase in daily sediment accumulation.

The 2-day windy event without precipitation within 9 days on 18-19 May, with daily average wind speed (and wind gust) of 2.0 (3.9) and 3.9 (7.1) m/s in the SW and NW directions, respectively, was followed by a significant increase in daily sediment accumulation, which lasted up to 3 days. Another 5-day windy event without precipitation within 21 days on 27-31 May, with daily average wind speed (and wind gust) of 3.2 (6.4), 2.8 (5.2), 1.9 (3.8), 3.6 (7.7), and $4.5(8.4) \mathrm{m} / \mathrm{s}$ in W, NW, W, W, and $\mathrm{W}$ directions, respectively, was followed by a significant increase in daily sediment accumulation, which lasted up to 6 days.

An independent-samples $t$-test was conducted to compare sedimentation flux rates in non-ice cover (group value 0 ) and ice cover (group value 1 ) conditions. There was a significant difference in the scores for non-ice cover (mean $=0.17, \mathrm{SD}=0.27$ ) and ice cover (mean $=0.04, \mathrm{SD}=0.12$ ) conditions $\left(t_{34}=5.48, p<0.001\right)$. Our results show that when there was no ice cover, the sedimentation flux rate increased. An independent-samples $t$-test was conducted to compare sediment flux rates in non-ground frost (group value 0 ) and ground frost (group value 1) conditions. There was a significant difference in the scores for non-ground frost (mean $=0.23, \mathrm{SD}=0.21$ ) and ground frost (mean $=0.07$, $\mathrm{SD}=0.06)$ conditions $\left(t_{15}=3.01, p=0.002\right)$. These results suggest that the occurrence of ground frost has a negative effect on the sedimentation flux rate.

\section{Discussion}

\subsection{Potential and Reliability of Online Sediment Trap}

Multiple high-resolution paleoclimatological studies from varved sediments have largely increased our understanding of past climate changes and their drivers and scales. Several studies have shown the link between lacustrine sediment accumulation and large-scale climatic patterns such as solar activity $[9,11,21,30,31]$ and changes in atmospheric circulation [9-12]. The detailed mechanisms by which catchments respond to large-scale climatic variability are very case-specific [2]. Detailed identification of the importance of specific weather and hydrological events will facilitate the interpretation of seasonal sedimentary records and improve proxy-based paleoclimatological records. Using online sediment traps with ultra-high (i.e., daily) resolution, it is possible to measure the variation of sediment fluxes in detail and develop our understanding of catchment processes and ultimately their climatic and hydrological controls.

In this study, we measured daily sediment accumulation flux rates to identify the importance of single climatic and hydrological events to sediment accumulation. Through automatic tomographic scanning of the sediment trap tube interior, we identified the daily changes of sediment accumulation rates with respect to meteorological events that were recorded at the meteorological station at the study site. The measured sediment volumes in the trap tube were very close to the manually measured sediment volumes (approximately $5 \%$ difference; Table 1), supporting the applicability of the tomographic scanning method for sediment flux rate studies. The deviation, however, increased up to $17 \%$ with very low sedimentation rates, which must be kept in mind if absolute values are compared. In most of the cases, tomographic scanning gave slightly larger values for sediment accumulation than manual measurements. However, even very low accumulation rates of less than $1 \mathrm{~mL} /$ day are recorded by tomographic scanning, and the theoretical accuracy of the method is $\pm 0.00995 \mathrm{~mL}$; the smallest 
measured value above zero was $0.00007 \mathrm{~mL} /$ day. The larger deviation of the October collection in the opposite direction compared to other measurements (Table 1 ) is very likely due to the sediment volume approaching the theoretical maximum. It seems that the practical maximum is slightly lower than the theoretical maximum. However, bearing these limitations in mind, we suggest that the trends, variability, and volumes of daily sediment accumulation are accurate enough to be used for monitoring of sediment flux variations. Large variability in the daily sediment flux data suggests the suitability of tomographic scanning for sediment flux measurements and underlines the need for ultra-high-resolution monitoring.

\subsection{Sediment Flux Changes Controlled by Meteorological and Hydrological Events}

Ultra-high-resolution observations and statistical analysis show a strong relationship between the rate of sediment accumulation in Savilahti Bay and meteorological and hydrological variables. The major parameters driving sediment accumulation on a seasonal scale are temperature, precipitation, and snow accumulation.

A positive correlation between sediment flux rate and temperature indicates spring, summer, and autumn as major seasons of sedimentation, which is in line with earlier sediment trap studies $[14,15]$ as well as the conceptual models of varve formation in boreal environments [15,30,32]. A drop in sedimentation rate occurs for periods with temperatures below zero (Figure 5). This most likely indicates decreased sediment availability due to freezing and frost, as discussed earlier $[4,14,21]$. The nearly simultaneous ice cover (Figure 4) shows a negative correlation with sediment flux. Ice cover forms a physical barrier to allochthonous material transport and to wind and wave stress, as suggested earlier [23]. The importance of the ice cover period and frost formation for reduced sediment accumulation is supported by the $t$-test (Figure 8 ), which shows that the majority of sediment accumulation occurred during the ice- and frost-free period. However, during the winter (December-February), minor sediment deposition occurred under ice cover. These individual sedimentation events are associated with periods of increased air temperature (Figure 5).

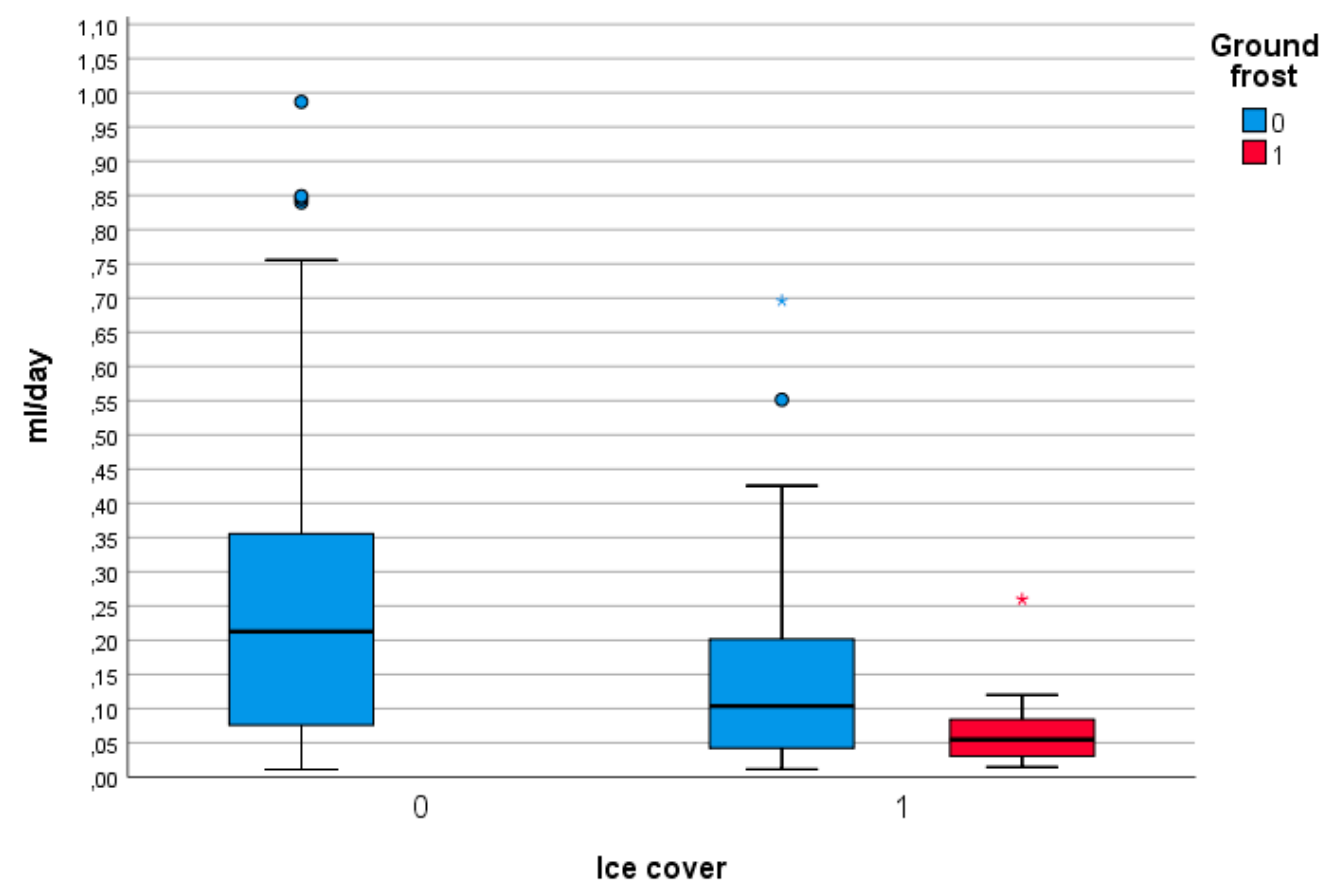

Figure 8. Boxplot of sediment flux rate with ice cover and ground frost grouping variables. Group value 0 means no ice cover and 1 means the presence of ice cover; for ground frost, group value 0 means no ground frost and 1 means the presence of ground frost at least in $1 \mathrm{~cm}$ deep. Note that the ground frost group value 1 boxplot is missing ice cover group 0, because there were no data for this group. Points represent outliers and asterisks represent extreme outliers. 
A negative correlation coefficient between sediment flux rate and snow depth reflects the importance of snowmelt or loss for increased sediment accumulation, as suggested earlier $[2,9,15,32]$. In spring (March-May), the sedimentation flux rate started to increase on 12 April. This peak was due to snowmelt-induced spring flooding. The peak sediment accumulation rates between 12 and 19 April occurred at a time of rapid snow cover thickness loss (Figure 4). It is noteworthy how short and punctuated the first period of extreme sediment volumes is in spring. The snow around the lake melted before the ice cover melted and caused solids to move under the ice. Ground frost started to decrease on 6 March and reached $0 \mathrm{~cm}$ on 16 April, almost simultaneously with ice cover melt. However, after the ice and soil melted, the sedimentation rate increased again from late May to early June. This could be related to spring algal blooms $[14,15,17]$; however, the tomography method is incapable of defining the type of accumulating material.

A positive correlation between sediment flux rate and water temperature is related to spring, summer, and autumn with unfrozen soil, but this flux rate is also very likely influenced by autochthonous production and enhanced accumulation of biogenic matter $[2,14,15,17]$. Tomographic scanning cannot identify the type of sedimentary material, and thus the accumulation of organic matter compared to minerogenic matter cannot be discussed based on these results.

Precipitation in general has well-documented links of sediment accumulation in boreal zones $[15,23,33]$. Interestingly, during summer (June-August), intense water precipitation events caused increased sediment influxes with durations of several days (Figure 6). The precipitation-induced erosion along with the increased stream velocity and surface run-off likely explain the positive correlations. The lag could be related to the catchment response linked to, e.g., hydrological connectivity and soil retention, but also to varying settling velocity of particles with different size and density. This highlights the importance of not only winter precipitation and consequent spring flood, but also precipitation during the growing season, to sediment accumulation.

A positive significant correlation with wind speed reflects wind speed increases, leading to an increase in sediment flux rate. Enhanced wind speed during summer months is often related to storms and high precipitation rates and therefore is difficult to separate from the dominating influence of precipitation. When air and water temperatures are positive, wind-induced waves are likely to cause resuspension of littoral sediments, as suggested earlier [23].

During autumn (September-November), in October, the sedimentation rate decreased and air temperature fell to negative values, the topsoil froze, and solids were no longer prone to erosion due to precipitation. Topsoil started to freeze on 27 October and short and long precipitation periods occurred on 5-19 November.

Unfortunately, massive construction work started on the immediate catchment of the Savilahti Bay on 27 July 2018, and the sediment flux response to autumn conditions cannot be discussed with respect to climatic and hydrologic data, but was most likely driven by ditching and digging. This also led to unpredicted filling of the trap tube close to the theoretical maximum limit, leading to failure in the measurement of total volume by tomography compared to manual measurement (Table 1). However, the online trapping technique seems to be a very useful and valuable instrument in sediment flux studies to facilitate our understanding of climate-catchment processes, and also for measuring and monitoring the influence of anthropogenic activities on lake catchments. Online sediment trapping enables the investigation of the influence of single storm events, wind speed, and frost formation on sediment accumulation, which are discussed when interpreting varve records $[2,4,15,21,23]$. Such events are suggested to influence the sediment supply and measured lamina thicknesses, but so far this has been difficult to address. Combining the detailed analyses of sediment components and annual varve records could lead to an even deeper understanding of the driving mechanisms of sediment accumulation and lamina thickness. Further studies utilizing the long-term online trapping technique from basins with annually laminated sediments and open data sources, such as meteorological and hydrological observations, and their combination with data and statistical analysis methods will 
deepen our understanding of catchment dynamics and thus improve future interpretation based on high-resolution sediment sequences such as varved sediment records and sediment trap datasets.

\section{Conclusions}

Ultra-high-resolution sedimentation flux rates combined with meteorological and hydrological observations provide valuable information about the response of catchments to weather conditions and facilitates the interpretation of varve records. Daily measurements allow for a better understanding of the influence of single meteorological events such as heavy rainfall or increased wind speed on sediment transport and accumulation. Using annually laminated sediments and sediment trapping with deployment periods of several weeks, it is difficult to address these short-term events in detail. The ultra-high-resolution sediment flux time series sheds light on catchment responses to seasonal conditions and single meteorological events. Statistical analysis and time series disclose seasonal effects on sedimentation in the semiclosed Savilahti Bay basin in eastern Finland. Evidence on the importance of precipitation and temperature for sediment deposition is gained. Moreover, increased sediment fluxes lasting for several days following rainstorm events and enhanced wind speed are measured. The online trapping technique seems to be a very useful and valuable instrument for sediment flux studies. Further studies utilizing a long-term online trap technique and open data sources, such as meteorological and hydrological observations, and their combination with data and statistical analysis methods are suggested in order to deepen our understanding of catchment dynamics. This will facilitate paleoclimatic interpretations based on high-resolution sediment sequences such as varved sediment records.

Author Contributions: Conceptualization, M.J. and S.S.; methodology, M.J.; software, M.J.; validation, M.J., S.S., and J.S.; formal analysis, S.S.; investigation, M.J.; writing-original draft preparation, M.J.; writing-review and editing, S.S. and J.S.; visualization, M.J.; supervision, S.S.; project administration, J.S.

Funding: This research received no external funding.

Acknowledgments: We would like to sincerely thank junior researcher Samuel Hartikainen, University of Eastern Finland, for help installing trapping equipment in the field.

Conflicts of Interest: The authors declare no conflict of interest.

\section{References}

1. Ojala, A.E.K.; Francus, P.; Zolitschka, B.; Besonen, M.; Lamoreux, S.F. Characteristics of sedimentary varve chronologies-A review. Quat. Sci. Rev. 2012, 43, 45-60. [CrossRef]

2. Zolitschka, B.; Francus, P.; Ojala, A.E.K.; Schimmelmann, A. Varves in lake sediments-A review. Quat. Sci. Rev. 2015, 117, 1-41. [CrossRef]

3. Schimmelmann, A.; Lange, C.; Schieber, J.; Francus, P.; Ojala, A.E.K.; Zolitschka, B. Varves in marine sediments: A review. Earth Sci. Rev. 2016, 159, 215-246. [CrossRef]

4. Saarni, S.; Lensu, A.; Tammelin, M.; Haltia, E.; Saarinen, T. Winter climate signal in boreal clastic-biogenic varves; a comprehensive analysis of three varved records from 1890 to $1990 \mathrm{AD}$ with meteorological and hydrological data from eastern Finland. GFF 2017, 139, 314-326. [CrossRef]

5. Amann, B.; Szidat, S.; Grosjean, M. A millennial-long record of warm season precipitation and flood frequency for the North-western Alps inferred from varved lake sediments: Implications for the future. Quat. Sci. Rev. 2015, 115, 89-100. [CrossRef]

6. Blass, A.; Bigler, C.; Grosjean, M.; Sturm, M. Decadal-scale autumn temperature reconstruction back to AD 1580 inferred from the varved sediments of Lake Silvaplana (southern Swiss Alps). Quat. Res. 2007, 68, 184-195. [CrossRef]

7. Moore, J.J.; Hughen, K.A.; Miller, G.H.; Overpeck, J.T. Little Ice Age recorded in summer temperature reconstructions from varved sediments of Donard Lake, Baffin Island, Canada. J. Paleolimnol. 2001, 25, 503-517. [CrossRef]

8. Brauer, A.; Dulski, P.; Mangili, C.; Mingram, J.; Liu, J. The potential of varves in high-resolution paleolimnological studies. Pages News 2009, 17, 96-98. [CrossRef] 
9. Ojala, A.E.K.; Launonen, I.; Holmström, L.; Tiljander, M. Effects of solar forcing and North Atlantic Oscillation on the climate of continental Scandinavia during the Holocene. Quat. Sci. Rev. 2015, 112, 153-171.

10. Ólafsdóttir, K.B.; Geirsdóttir, Á.; Miller, G.H.; Larsen, D.J. Evolution of NAO and AMO strength and cyclicity derived from a 3-ka varve-thickness record from Iceland. Quat. Sci. Rev. 2013, 69, 142-154. [CrossRef]

11. Brauer, A.; Haug, G.H.; Dulski, P.; Sigman, D.M.; Negendank, J.F.W. An abrupt wind shift in western Europe at the onset of Younger Dryas cold Period. Nat. Geosci. 2008, 1, 520-523. [CrossRef]

12. Schletter, G.; Liu, Q.; Mingram, J.; Stebich, M.; Dulski, P. East-Asian monsoon variability between 15000 and 2000 cal. yr BP recorded in varved sediments of Lake Sihailongwan (northeastern China, Long Gang volcanic field). Holocene 2006, 16, 1043-1057. [CrossRef]

13. Landmann, G.; Reimer, A.; Lemcke, G.; Kempe, S. Dating Late Glacial abrupt climate changes in the $14,570 \mathrm{yr}$ long continuous varve record of Lake Van, Turkey. Palaeogeogr. Palaeoclimatol. Palaeoecol. 1996, 122, 107-118. [CrossRef]

14. Bonk, A.; Tylmann, W.; Amann, B.; Enters, D.; Grosjean, M. Modern limnology, sediment accumulation and varve formation processes in Lake Zabinskie, northeastern Poland: Comprehensive process studies as a key to understand the sediment record. J. Limnol. 2015, 74, 358-370. [CrossRef]

15. Ojala, A.E.K.; Kosonen, E.; Wecström, J.; Korkonen, S.; Korhola, A. Seasonal formation of clastic-boigenic varves: Potential for paleoenvironmental interpretations. GFF 2013, 135, 237-247. [CrossRef]

16. Trapote, M.C.; Vegas-Vilarrúbia, T.; López, P.; Puche, E.; Gomà, J.; Buchaca, T.; Cañellas-Boltà, N.; Safont, E.; Corella, J.P.; Rull, V. Modern sedimentary analogues and integrated monitoring to understand varve formation in the Mediterranean Lake Montcortès (Central Pyrenees, Spain). Palaeogeogr. Palaeoclimatol. Palaeoecol. 2018, 496, 292-304. [CrossRef]

17. Kaal, J.; Cortizas, A.M.; Rydberg, J.; Bigler, C. Seasonal changes in molecular composition of organic matter in lake sediment trap material from Nylandssjön, Sweden. Org. Geochem. 2015, 83-84, 253-262. [CrossRef]

18. Chu, G.; Liu, J.; Schettler, G.; Li, J.; Sun, Q.; Gu, Z.; Lu, H.; Liu, Q.; Liu, T. Sediment Fluxes and Varve Formation in Sihailongwan, a Maar Lake from Northeastern China. J. Paleolimnol. 2015, 34, 311-324. [CrossRef]

19. Tylmann, W.; Szpakowska, K.; Ohlendorf, C.; Woszczyk, M.; Zolitschka, B. Conditions for deposition of annually laminated sediments in a small meromictic lakes: A case study of Lake Suminko (northern Poland). J. Paleolimnol. 2012, 47, 55-70. [CrossRef]

20. Kienel, U.; Kirillin, G.; Brademann, B.; Plessen, B.; Lampe, R.; Brauer, A. Effects of spring warming and mixing duration on diatom deposition in deep Tiefer See, NE Germany. J. Paleolimnol. 2017, 57, 37-49. [CrossRef]

21. Saarni, S.; Muschitiello, F.; Weege, S.; Brauer, A.; Saarinen, T. A late Holocene record of solar-forced atmospheric blocking variability over Northern Europe inferred from varved lake sediments of Lake Kuninkaisenlampi. Quat. Sci. Rev. 2016, 154, 100-110. [CrossRef]

22. Martin-Puertas, C.; Brauer, A.; Dulski, P.; Brademann, B. Testing climate-proxy stationarity throughout the Holocene: An example from the varved sediments of Lake Meerfelder Maar (Germany). Quat. Sci. Rev. 2012, 58, 56-65. [CrossRef]

23. Itkonen, A.; Salonen, V.-P. The response of sedimentation in three varved lacustrine sequences to air temperature, precipitation and human impact. J. Paleolimnol. 1994, 11, 323-332. [CrossRef]

24. The Finnish Meteorological Institute's Open Data. Available online: https://en.ilmatieteenlaitos.fi/open-data (accessed on 30 March 2019).

25. Finland's Environmental Administration, Hydrological Observations. Available online: https://www. ymparisto.fi/en-US/Maps_and_statistics/Hydrological_observations (accessed on 30 March 2019).

26. Saarnisto, M. Shoreline displacement and emergence of lake basins. Geological Survey of Finland. Spec. Pap. 2000, 29, 25-34.

27. Eronen, M.; Haila, H. Geologinen kehitys jääkauden lopussa. In Atlas of Finland, Surficial Deposits; Alalammi, P., Ed.; National Board of Survey and Geographical Society of Finland: Helsinki, Finland, 1990; Volume 124, pp. 13-19. (In Finnish)

28. Johansson, M.; Saarni, S.; Sorvari, J. A modern on-line technology for environmental monitoring: Tomographic approach in sediment trap provides record of sediment flux with ultra-high-resolution. Forthcoming.

29. IBM Corp. IBM SPSS Statistics for Windows, Version 25.0; IBM Corp.: Armonk, NY, USA, 2017. 
30. Haltia-Hovi, E.; Saarinen, T.; Kukkonen, M. A 2000-year record of solar forcing on varved lake sediments in eastern Finland. Quat. Sci. Rev. 2007, 26, 678-689. [CrossRef]

31. Czymzik, M.; Brauer, A.; Dulski, P.; Plessen, B.; Naumann, R.; von Grafesnstein, U.; Scheffler, R. Orbital and solar forcing of shifts in Mid- to Late Holocene flood intensity from varved sediments of pre-Alpine Lake Ammersee (southern Germany). Quat. Sci. Rev. 2015, 61, 96-110. [CrossRef]

32. Renberg, I. Formation, structure and visual appearance of iron-rich, varved lake sediments. Proc. Int. Assoc. Theor. Appl. Limnol. 1981, 21, 1922-2010. [CrossRef]

33. Saarni, S.; Saarinen, T.; Lensu, A. Organic lacustrine sediment varves as indicators of past precipitation chamges: A 3000-year climate record from Central Finland. J. Paleolimnol. 1995, 53, 401-413. [CrossRef]

(C) 2019 by the authors. Licensee MDPI, Basel, Switzerland. This article is an open access article distributed under the terms and conditions of the Creative Commons Attribution (CC BY) license (http://creativecommons.org/licenses/by/4.0/). 